\title{
Pengembangan Blended Learning untuk Mata Kuliah Pengembangan Media Sederhana Teknologi Pendidikan
}

\author{
Muhammad Alifuddin Imam, ${ }^{1 \otimes}$ Cecep Kustandi, Retno Widyaningrum ${ }^{2}$ \\ ${ }^{1}$ Universitas Negeri Jakarta, Jakarta, Indonesia. \\ ${ }^{2}$ Universitas Negeri Jakarta, Jakarta, Indonesia. \\ 3 Universitas Negeri Jakarta, Jakarta, Indonesia.
}

DOI: https://doi.org/10.21009/JPI.031.13

\begin{tabular}{l}
\hline Article History \\
\hline Received : 2020 \\
Accepted : 2020 \\
Published : 2020 \\
\hline Keywords \\
\hline Blended Learning; \\
Integrative Learning \\
Design Framework; \\
Online Learning; \\
Educational \\
Technology. \\
\hline
\end{tabular}

\begin{abstract}
Abstrak
Penelitian ini bertujuan untuk mengembangkan sebuah prototype blended learning untuk mata kuliah Pengembangan Media Sederhana di Program Studi Teknologi Pendidikan, Universitas Negeri Jakarta. Pengembangan blended learning ini menggunakan model ILDF (Integrative Learning Design Framework) dengan melalui tiga tahapan yaitu eksplorasi, penyusunan dan evaluasi dengan responden yakni ahli materi 1 orang, ahli media 1 orang dan responden one-to-one 5 orang. Dalam penggunaan model ILDF ada 3 tahap yang dilakukan yaitu (1) tahap eksplorasi: menganalisis keadaan yang ada sehingga nantinya akan menjadi acuan dalam mengembangkan pembelajaran blended; (2) tahap penyusunan: melakukan penyusunan produk yang dikembangkan mengacu pada hasil dalam tahap eksplorasi berupa desain pembelajaran berformat blended, prototype media pembelajaran dan materi serta program blended learning secara keseluruhan; dan (3) tahap evaluasi: melakukan expert review dengan ahli materi yang menunjukkan hasil yang baik dengan presentase $79,25 \%$, expert review ahli media yang menunjukkan hasil yang baik dengan presentase $85 \%$ dan hasil ujicoba responden one-to-one menunjukkan hasil yang baik dengan presentase 70,25\%.
\end{abstract}

\begin{abstract}
This study aims to develop a prototype of blended learning, in the Simple Media Development course in the Education Technology Study Program, Universitas Negeri Jakarta. The development of blended learning uses ILDF (integrative learning design framework) model through three stages, namely exploration, compilation and evaluation with respondents, namely 1 material expert, 1 person media expert and 5 person one-to-one respondent. In the use of ILDF models there are 3 stages carried out namely, (1) the exploration phase: analyzing the existing conditions so that later it will become a reference in developing blended learning; (2) drafting stage: making the product development that is developed refers to the results in the exploration stage in the form of a blended format learning design, prototype of learning media and materials as well as a blended learning program as a whole; and (3) evaluation stage: conducting expert reviews with material experts who show good results with a percentage of $79.25 \%$, expert expert media reviews that show good results with a percentage of $85 \%$ and the results of one-to-one respondents' trials show good results. good with $70.25 \%$ percentage.
\end{abstract}

\footnotetext{
${ }^{\square}$ Corresponding author : Muhammad Alifuddin Imam Adress: Universitas Negeri Jakarta

Jakata, Indonesia

E-mail: alifuddinimam@gmail.com
}

(C) 2020 Universitas Negeri Jakarta 


\section{PENDAHULUAN}

Belajar adalah suatu proses yang dilakukan oleh setiap orang karena berinteraksi dengan lingkungan sekitarnya sehingga menyebabkan suatu perubahan pada tingkat pengetahuan, keterampilan ataupun sikap. Untuk mendukung terjadinya proses belajar, tiap orang membutuhkan media atau perantara baik itu berupa manusia, benda atau materi maupun suatu peristiwa yang dapat menyebabkan perubahan tingkah laku, pengetahuan ataupun sikap.

Media yang digunakan dalam proses belajar cenderung diartikan sebagai alat seperti buku, grafis, foto dan alat elektronik seperti televisi, radio maupun komputer, dalam hal ini media-media tersebut dikatakan sebagai media pembelajaran. Tujuan digunakannya media pembelajaran dalam proses belajar adalah untuk memudahkan dan membuat proses pembelajaran menjadi lebih interaktif sehingga membuat peserta didik menjadi lebih aktif dan menumbuhkan minat belajar. Media pembelajaran dapat dikategorikan menjadi berbagai jenis mulai dari media cetak dan noncetak, media yang sederhana dan media yang canggih (modern) ataupun media visual, audio dan audiovisual. Pemilihan media pembelajaran harus memperhatikan banyak hal mulai dari tujuan pembelajaran, ketersediaan sumber, dana, tenaga ahli dan karakteristik peserta didik.

\section{Prodi Teknologi Pendidikan}

Universitas Negeri Jakarta salah satu keahliannya ialah dapat mengembangkan media untuk memfasilitasi peserta didik agar dapat meningkatkan kinerja belajarnya. Salah satu mata kulliah prodi Teknologi Pendidikan adalah Pengembangan Media Sederhana (PMS). Mata kuliah ini mengkaji tentang penggunaan media-media sederhana untuk memfasilitasi proses pembelajaran mulai dari pemilihan media, perancangan media sampai dengan penggunaan dan evaluasi media sederhana tersebut. Tugas-tugas yang ada dalam mata kuliah ini ialah membuat produk yang dapat digunakan untuk menunjang proses pembelajaran diantaranya berupa slogan, skala, poster, flashcard, flipchart ataupun 3 dimensi.
Berdasarkan wawancara dengan Ibu Diana Ariani sebagai dosen pengampu mata kuliah Pengembangan Media Sederhana peneliti memperoleh informasi mengenai bagaimana proses penyelenggaraan pembelajaran yang ada dalam mata kuliah ini. Materi mata kuliah mengalami pembaruan dan pengkajian materi baru dan mengalami beberapa kendala diantaranya:

1. Adanya perubahan dan pengintegrasian mata kuliah satu dengan yang lainnya membuat beberapa materi dan bahan ajar mata kuliah pengembangan media sederhana belum ada;

2. Karena pergantian dosen pengampu, strategi pembelajaran yang dilakukan ialah hanya menggunakan metode konvensional face-to-face dan praktik sehingga dirasa kurang variatif;

3. Kurang adanya sumber belajar yang dapat dengan mudah diakses dan praktis oleh peserta didik ketika sedang melaksanakan praktik pengembangan media sederhana.

Kendala yang ada dalam mata kuliah PMS haruslah dipecahkan dengan solusi dan intervensi yang tepat. Intervensi yang dapat dilakukan ialah dengan mengembangkan Blended Learning dalam pembelajaran mata kuliah Pengembangan Media Sederhana.

Menurut Clark dan Mayer, e-learning merupakan pembelajaran yang disampaikan melalui teknologi digital seperti komputer atau perangkat mobile yang bertujuan untuk mendukung terjadinya belajar. Proses pembelajaran yang menggunakan konsep elearning ini, memudahkan peserta didik untuk mengakses materi pembelajaran secara mudah dan cepat tanpa batas jarak dan waktu melalui penggunaan teknologi internet.

Pemilihan Blended Learning dilakukan karena pembelajaran menggabungkan pembelajaran tatap muka dan online learning yang akan mengatasi keterbatasan waktu dan dapat mempermudah peserta didik dalam mengakses sumber belajar dengan mudah. Blended learning juga dapat memfasilitasi proses komunikasi yang berlangsung dalam pembelajaran melalui fitur chat ataupun forum 
dan diskusi, sehingga setelah peserta didik turun kelapangan mereka akan memiliki waktu lebih untuk merancang media yang akan dihasilkan tanpa harus melalui proses tatap muka.

\section{METODE}

Penelitian ini menggunakan model pengembangan Integrativ Learning Design Framework (ILDF). Model pengembangan ini akan berorientasi pada produk yang terdiri dari tiga tahapan/langkah utama yaitu eksploration, enactment, evaluation.

\section{Tahap Eksploration}

Pada tahap ini pengembang melakukan identifikasi dan analisis masalah pada tempat dan juga kebutuhan pembelajaran pengguna dimana pembelajaran online tersebut akan diimplementasikan. Tahap eksplorasi ini terbagi menjadi beberapa sub tahapan lagi untuk akhirnya mendapatkan informasi terkait masalah maupun solusi apa yang dapat digunakan untuk menyelesaikannya. Beberapa sub tahapan tersebut yakni:

\section{a. Analisis Kebutuhan}

Pada tahap analisis kebutuhan, kegiatan yang dilakukan peneliti adalah mengobservasi lingkungan belajar yang ada di prodi Teknologi
Pendidikan Universitas Negeri Jakarta khususnya pada mata kuliah pengembangan sederhana. Ini dimaksudkan untuk mengetahui seperti apa bentuk proses belajar yang terjadi selama ini dilakukan prodi Teknologi Pendidikan khususnya pada mata kuliah pengembangan media sederhana yang

nantinya akan menjadi acuan awal peneliti mengembangkan sebuah produk berdasarkan dari informasi yang telah di dapat sebelumnya.

\section{b. Survey Literatur}

Pada tahap survey literature ini kegiatan yang dilakukan peneliti adalah dengan meninjau atau mensurvey terkait faktor pendukung dan penghambat dalam pengembangan blended learning pada pembelajaran mata kuliah pengembangan media sederhana. Ini dimaksudkan untuk mengetahui platform apa yang digunakan dalam pembelajaran online seperti apa kinerja platform tersebut, strategi apa yang digunakan oleh pengembang untuk membuat blended learning yang dapat menarik minat mahasiswa dalam belajar, seperti apa konten pembelajaran yang dikembangkan, dan bagaimana konten pembelajaran tersebut disajikan. Yang hasil dari informasi yang didapat tersebut akan berupa model pedagogis dan strategi instruksional yang menjadi tinjauan peneliti di dalam pengembangan yang akan

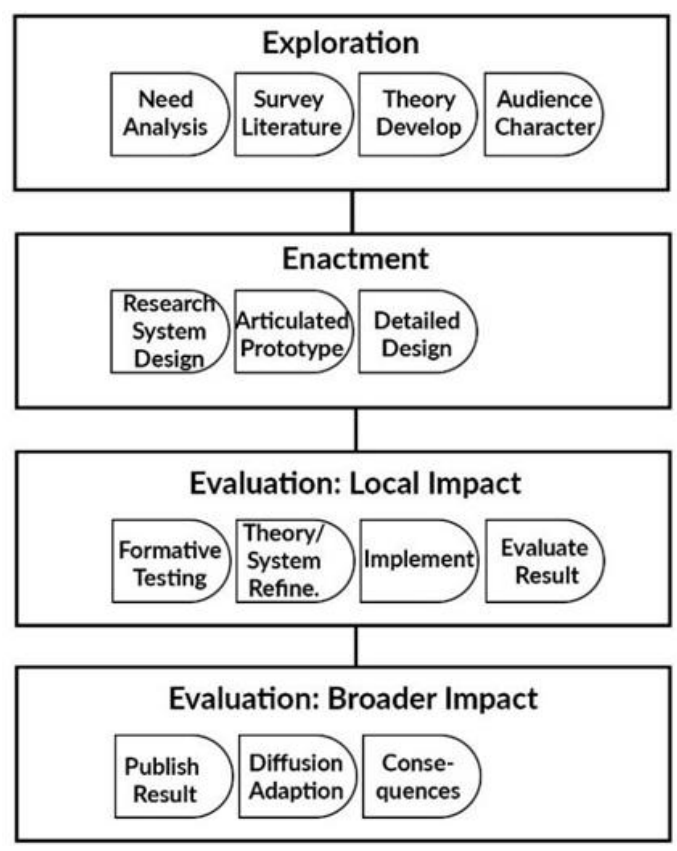

Gambar 1 Model Pengembangan Integrative Learning Design Framework 
dillakukan.

\section{c. Pengembangan Teori}

Pada tahap pengembangan teori ini kegiatan yang dilakukan peneliti adalah melakukan benchmarking (pembandingan) pada berbagai teori yang telah ada sebelumnya yang kemudian peneliti akan memilih teori-teori yang sesuai untuk pengembangan blended learning pada mata kuliah pengembangan media sederhana.

\section{d. Karakteristik Peserta Didik}

Pada tahap audience characterization ini kegiatan yang dilakukan peneliti adalah melakukan survey dan pemberian angket pada mahasiswa/mahasiswi yang telah mengikuti mata kuliah pengembangan media sederhana terkait dengan sumber belajar mereka selama mengikuti pembelajaraan mata kuliah tersebut. Ini dimaksudkan untuk mengetahui pengalaman belajar, gaya belajar, dan bagaimana mereka mendapatkan sumber belajar mereka selama mengikuti mata kuliah pengembangan media sederhana

\section{Tahap Enactment (Penyusunan)}

Pada tahap ini pengembang melakukan pemetaan dari informasi yang telah di dapat dari tahap eksplorasi menjadi sebuah rancangan atau konsep. Tahap enactment atau penyusunan disini memiliki beberapa sub tahapan, beberapa sub tahapan tersebut yakni:

\section{a. Pengembangan Desain Penelitian/Desain Pengembangan}

Pada tahap ini kegiatan yang dilakukan adalah meneliti terkait berbagai informasi yang telah di dapatkan dari tahap sebelumnya yakni tahap explorasi mulai dari model pembelajaran sampai teori pada proses belajarnya. Ini dimaksudkan untuk menjabarkan seluruh informasi yang di dapat yang akan digunakan untuk pengembangan blended learning pada mata kuliah pengembangan media sederhana. Yang hasilnya peneliti akan menggunakan teori dan model pembelajaran tersebut sebagai acuan untuk pengembangan blended learning pada mata kuliah pengembangan media sederhana.

\section{b. Pengembangan Prototype Produk}

Pada tahap pengembangan prototype produk ini kegiatan yang dilakukan peneliti adalah merancang bentuk awal atau protoype dan produk blended learning yang akan diimplementasikan

pada pembelajaran mata kuliah pengembangan media sederhana dari seluruh kegiatan pada sub tahap sebelumnya yakni research/system design. Hasilnya akan menjadi sebuah prototype dari blended learning untuk mata kuliah pengembangan media sederhana yang mengandung unsur-unsur yang dibutuhkan di dalam membantu mata kuliah tersebut menjadi lebih efektif.

\section{c. Pengembangan Desain Produk secara} Detail

Pada tahap pengembangan desain produk secara detail ini kegiatan yang peneliti lakukan adalah mengkaji kembali dan memperinci produk yang berupa prototype dan mengembangkan materi yang ada didalamnya yang kemudian akan dimasukkan atau diimplementasikan ke dalam platform. Yang hasilnya ialah sebuah produk blended learning yang lebih matang dan dokumentasi dari setiap langkah atau proses produksi dari pengembangan tersebut.

\section{Tahap Evaluation}

Pada tahap ini pengembang melakukan evaluasi terhadap sistem yang telah dirancang dan melihat sejauh mana dampak pembelajaran dengan menggunakan rancangan tersebut. Tahap evaluasi disini memiliki beberapa sub tahapan, beberapa sub tahapan tersebut yakni:

\section{a. Tes Formatif}

Tes formatif dilakukan setelah produk dikembangkan dan diunggah dalam web pembelajaran online di halaman fip.unj.ac.id/hylearn. Produk dikembangkan oleh peneliti lalu diuji coba kepad expert review (ahli materi dan ahli media) dan ujicoba kepada mahasis melalui evaluasi one to one. 


\section{b. Perbaikan Produk}

Hasil uji coba dalam tahap tes formatif dijadikan sebagai dasar untuk penyempurnaan produk pembelajaran blended. Segala kekurangan dan masukan dari responden disempurkan dengan melakukan revisi produk.

\section{HASIL DAN PEMBAHASAN}

Penelitian pengembangan ini menghasilkan program pembelajaran berbasis blended learning pada mata kuliah Pengembangan Media Sederhana. Pengembangan pembelajaran berbasis blended learning ini menggunakan model pengembangan Integrativ Learning Design Framework (ILDF). Model pengembangan ini akan berorientasi pada produk yang terdiri dari tiga tahapan/langkah utama sebagai berikut.

\section{Tahap Exploration}

\section{a. Analisis Kebutuhan}

Pada tahap analisis kebutuhan ini hasil yang diperoleh yaitu kebutuhan pengembangan pembelajaran blended untuk mata kuliah Pengembangan Media Sederhana.

Tabel 1 Hasil Analisis Kebutuhan

\begin{tabular}{|c|c|c|}
\hline Aspek & Kesenjangan & Kebutuhan \\
\hline $\begin{array}{l}\text { Durasi } \\
\text { Pembelajaran }\end{array}$ & $\begin{array}{l}\text { Mahasiswa } \\
\text { cenderung akan } \\
\text { merasa bosan } \\
\text { seiring } \\
\text { berjalannya } \\
\text { proses belajar } \\
\text { karena kurang } \\
\text { variatifnya } \\
\text { metode } \\
\text { pembelajaran. }\end{array}$ & $\begin{array}{l}\text { Desain } \\
\text { pembelajaran } \\
\text { dibuat secara } \\
\text { blended } \\
\text { sehingga } \\
\text { memungkinkan } \\
\text { mahasiswa } \\
\text { untuk } \\
\text { mengakses } \\
\text { materi diluar } \\
\text { waktu pembelajaran di } \\
\text { kelas yang } \\
\text { terbatas. }\end{array}$ \\
\hline $\begin{array}{l}\text { Metode dan } \\
\text { Strategi } \\
\text { Pembelajaran }\end{array}$ & $\begin{array}{l}\text { Metode } \\
\text { konvensional } \\
\text { dan diskusi } \\
\text { kelompok } \\
\text { memakan waktu } \\
\text { cukup lama } \\
\text { sehingga waktu } \\
\text { mahasiswa } \\
\text { dalam } \\
\text { melakukan } \\
\text { praktik kurang. }\end{array}$ & $\begin{array}{l}\text { Metode } \\
\text { konvensional } \\
\text { dan diskusi } \\
\text { kelompok } \\
\text { dikombinasikan } \\
\text { melalui } \\
\text { pembelajaran } \\
\text { online sehingga } \\
\text { waktu untuk } \\
\text { membahas } \\
\text { materi dapat } \\
\text { berjalan di luar } \\
\text { kelas dan } \\
\text { metode praktik }\end{array}$ \\
\hline
\end{tabular}

\begin{tabular}{|c|c|c|}
\hline & & $\begin{array}{l}\text { memiliki waktu } \\
\text { yang cukup. }\end{array}$ \\
\hline $\begin{array}{l}\text { Media dan } \\
\text { Sumber } \\
\text { Belajar }\end{array}$ & $\begin{array}{l}\text { Media dan } \\
\text { sumber belajar } \\
\text { belum dapat } \\
\text { memenuhi } \\
\text { kebutuhan } \\
\text { mahasiswa } \\
\text { dalam } \\
\text { pembelajaran }\end{array}$ & $\begin{array}{l}\text { Media dan } \\
\text { sumber belajar } \\
\text { yang beragam } \\
\text { dapat } \\
\text { menunjang } \\
\text { aktivitas } \\
\text { pembelajaran } \\
\text { mahasiswa } \\
\text { serta membantu } \\
\text { mahasiswa } \\
\text { mendalami } \\
\text { materi }\end{array}$ \\
\hline
\end{tabular}

Analisis yang dilakukan berdasarkan kesenjangan yang ada yakni pembelajaran pengembangan media sederhana dapat dirancang dalam bentuk blended learning untuk mengatasi kesenjangan yang ada sehingga pelaksanaan blended learning yang mana menggabungkan pembelajaran tatap muka dengan pembelajaran online yang menjadikan intervensi untuk diterapkan sesuai kebutuhan.

\section{b. Survey Literatur}

Pada tahap ini hasil yang diperoleh adalah daftar literatur yang digunakan sebagai acuan dalam pengembangan pembelajaran blended learning. Pengembangan pembelaaran dalma bentuk blended untuk mata kuliah pengembangan media sederhana didasarkan teori pendukung yang sesuai denan kaidahkaidah kelimuan, oleh karena itu literatur yang dipakai sebagai dasar pengembangan ini adalah.

Tabel 2 Daftar Literatur Pendukung

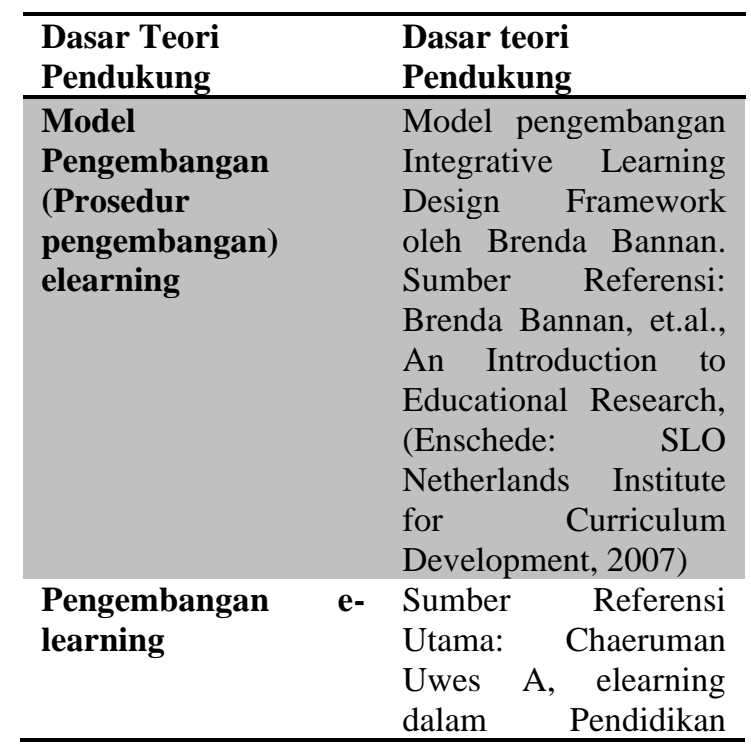




\begin{tabular}{|c|c|}
\hline & $\begin{array}{lr}\text { Jarak Jauh } & \text { (Pusat } \\
\text { Informasi } & \text { dan } \\
\text { Komunikasi } & \\
\text { Pendidikan:2010 } & \end{array}$ \\
\hline $\begin{array}{l}\text { Penyelenggaraan } \\
\text { pembelajaran } \\
\text { blended learning }\end{array}$ & $\begin{array}{lr}\text { Sumber } & \text { Referensi } \\
\text { Utama: } & \text { Allison } \\
\text { Littlejohn dan Chris } & \text { Pegles, Preparing for } \\
\text { Blended } & \text { e-learning, } \\
\text { (Oxon: } & \text { Routlegde, } \\
\text { 2007) } & \end{array}$ \\
\hline $\begin{array}{l}\text { Penyelenggaraan } \\
\text { learning object }\end{array}$ & $\begin{array}{l}\text { Sumber Referensi } \\
\text { Utama: Dewi S. } \\
\text { Prawiladilaga, Mozaik } \\
\text { Teknologi Pendidikan: } \\
\text { e-learning (Jakarta: } \\
\text { Kencana, 2013 }\end{array}$ \\
\hline $\begin{array}{l}\text { Pengembangan } \\
\text { materi perkuliahan } \\
\text { Pengembangan } \\
\text { Media Sederhana }\end{array}$ & $\begin{array}{lr}\text { Sumber } & \text { Referensi } \\
\text { Utama: } & \text { Cecep } \\
\text { Kustandi dan Bambang } \\
\text { Sutjipto, } \\
\text { Pembelajaran: } \\
\text { dan Digital (Jakarta: } \\
\text { Ghalia Indonaesia, } \\
2011\end{array}$ \\
\hline
\end{tabular}

\section{c. Pengembangan Teori}

Hasil yang diperoleh dari langkah pengembangan teori adalah gabungan antara teori-teori yang digunakan dalam penelitian pembelajaran dengan hasil temuan pada tahap analisis kebutuhan. Pengembangan teori pembelajaran blended learning untuk mata kuliah Pengembangan Media Sederhana meliputi berbagai aspek yang berawal dari pengenalan media, macam-macam media, hal yang harus diperhatikan dalam menyusun media hingga tata cara mengembangkan media sederhana secara lengkap berdasarkan pendapat dan teori para ahli. Adapun topiktopik essensial yang akan dibelajarkan dalam mata kuliah pengembangan media sederhana dapat dijabarkan dalam tabel berikut ini:

Tabel 3 Kerangka Topik dan Materi

\begin{tabular}{lll}
\hline No. & Pokok Bahasan & Sub-Pokok Bahasan \\
\hline 1. & $\begin{array}{l}\text { Konsep dasar } \\
\text { Media } \\
\text { Pembelajaran }\end{array}$ & $\begin{array}{l}\text { - Pengertian, Fungsi } \\
\text { dan Manfaat Media } \\
\text { Pembelajaran } \\
\text { - Taksonomi Media }\end{array}$ \\
2. & $\begin{array}{l}\text { Prinsip dan } \\
\text { Unsur Disain }\end{array}$ & $\begin{array}{l}\text { - Prinsip Disain } \\
\text { Pesan } \\
\end{array}$ \\
\end{tabular}

\begin{tabular}{|c|c|c|}
\hline 3. & $\begin{array}{l}\text { Jenis }- \text { jenis } \\
\text { Media }\end{array}$ & $\begin{array}{l}\text { - Media } 2 \text { Dimensi } \\
\text { - Media } 3 \text { Dimensi }\end{array}$ \\
\hline 4. & $\begin{array}{l}\text { Perencanaan } \\
\text { Pengembangan } \\
\text { Media } \\
\text { Sederhana }\end{array}$ & $\begin{array}{l}\text { - } \text { Penyusunan } \\
\text { Rancangan } \\
\text { Pengembangan } \\
\text { - Pemilihan dan } \\
\text { Penggunaan Media }\end{array}$ \\
\hline 5. & $\begin{array}{l}\text { Pengembangan } \\
\text { Media } \\
\text { Sederhana }\end{array}$ & $\begin{array}{l}\text { - Mengembangkan } \\
\text { Media } 2 \text { Dimensi } \\
\text { - Mengembangkan } \\
\text { Media } 3 \text { Dimensi }\end{array}$ \\
\hline
\end{tabular}

\section{d. Karakteristik Peserta Didik}

Pada langkah ini hasil yang diperoleh adalah profil peserta didik yang mengikuti mata kuliah pengembangan media sederhana. Untuk mendapatkan profil mahasiswa yang mengikuti mata kuliah tersebut, pengembang menyebarkan kuisioner berbentuk online form melalui platform Google. Form yang disebarkan kepada responden yaitu mahasiwa Teknologi Pendidikan angakatan 2018 yang mengikuti mata kuliah Pengembangan Media Sederhana.

Kuisioner disebarkan kepada mahasiswa Teknologi Pendidikan Angkatan 2018 dengan 10 orang responden, Adapun hasil yang diperoleh yaitu profil karakteristik peserta didik sebagai berikut:

Tabel 4 Analisis Profil Peserta Didik

\begin{tabular}{ll}
\hline Aspek & Deskripsi \\
\hline Usia & Mahasiswa yang akan \\
& mengikuti mata kuliah \\
& Pengembangan Media \\
& Sederhana berusia 19-20 \\
& tahun dengan lebih dari \\
& setengahnya dari jumlah \\
& responden berusia 19 tahun
\end{tabular}




\begin{tabular}{|c|c|}
\hline & $\begin{array}{l}\text { pembelajaran yang dapat } \\
\text { diakses selama } 24 \text { jam. }\end{array}$ \\
\hline $\begin{array}{l}\text { Lokasi belajar } \\
\text { selain di kampus }\end{array}$ & $\begin{array}{l}\text { Aspek lokasi belajar selain } \\
\text { di kampus menunjukkan } \\
\text { bahwa lebih dari setengah } \\
\text { mahasiswa melakukan } \\
\text { proses belajar di rumah. }\end{array}$ \\
\hline Kepemilikan & Aspek kepemilikan \\
\hline $\begin{array}{l}\text { komputer/Laptop/ } \\
\text { Gawai }\end{array}$ & $\begin{array}{l}\text { komputer/laptop/gawai } \\
\text { menunjukkan bahwa } \\
\text { seluruh mahasiswa } \\
\text { memiliki komputer/laptop, } \\
\text { artinya pembelajaran } \\
\text { online dapat diakses oleh } \\
\text { mahasiswa melalui } \\
\text { komputer/laptop/gawai } \\
\text { pribadi. }\end{array}$ \\
\hline Akses internet & $\begin{array}{l}\text { Aspek akses internet yang } \\
\text { digunakan oleh mahasiswa } \\
\text { menunjukkan bahwa } \\
\text { sebagian besar (80\%) } \\
\text { menggunakan akses } \\
\text { internet melalui kuota } \\
\text { paket internet provider dan } \\
\text { sisanya menggunakan } \\
\text { akses wifi kampus. }\end{array}$ \\
\hline $\begin{array}{l}\text { Pengalaman } \\
\text { belajar melalui } \\
\text { internet }\end{array}$ & $\begin{array}{l}\text { Pada aspek pengalaman } \\
\text { belajar melalui internet } \\
\text { menunjukkan bahwa } \\
\text { semua mahasiswa memiliki } \\
\text { pengalaman belajar melalui } \\
\text { internet dan semua tertarik } \\
\text { untuk mengikuti } \\
\text { pembelajaran } \\
\text { menggunakan teknologi } \\
\text { internet. }\end{array}$ \\
\hline Gaya Belajar & $\begin{array}{l}\text { Pada aspek gaya belajar } \\
\text { menunjukkan bahwa } \\
\text { sebesar } 80 \% \text { memiliki gaya } \\
\text { belajar visual. }\end{array}$ \\
\hline
\end{tabular}

\section{Tahap Penyusunan}

Tahap selanjutnya dalam pengembangan blended learning untuk mata kuliah pengembangan media sederhana yaitu penyusunan produk pembelajaran blended. Pada tahap ini, informasi-informasi yang telah didapatkan di tahap sebelumnya yaitu tahap eksplorasi yang menjadi acuan untuk menyususn produk sehingga sesuai dengan kondisi actual yang ada di lapangan. Berikut langkah-langkah yang ada pada tahap ini:

\section{a. Desain Program}

Pada langkah ini, pengembang menyusun desain pembelajaran blended untuk mata kuliah pengembangan media sederhana. Adapun produk yang dihasilkan dalam langkah ini yakni:

Tabel 5 Contoh Penentuan Aktivitas Pembelajaran Blended

\begin{tabular}{|c|c|c|c|c|}
\hline \multirow[t]{3}{*}{$\begin{array}{c}\text { CAPAIAN } \\
\text { PEMBELAJA } \\
\text { RAN }\end{array}$} & \multirow[t]{3}{*}{$\begin{array}{c}\text { POKOK } \\
\text { BAHASAN }\end{array}$} & \multirow[t]{3}{*}{$\begin{array}{c}\text { SUB-POKOK } \\
\text { BAHASAN }\end{array}$} & \multicolumn{2}{|c|}{$\begin{array}{c}\text { AKTIVITA } \\
\text { S } \\
\text { PEMBELAJ } \\
\text { ARAN }\end{array}$} \\
\hline & & & $\begin{array}{c}\text { Sinkr } \\
\text { on }\end{array}$ & $\begin{array}{l}\text { Asi } \\
\text { nk } \\
\text { ron }\end{array}$ \\
\hline & & & $\begin{array}{ll}S & S \\
L & M\end{array}$ & \\
\hline
\end{tabular}

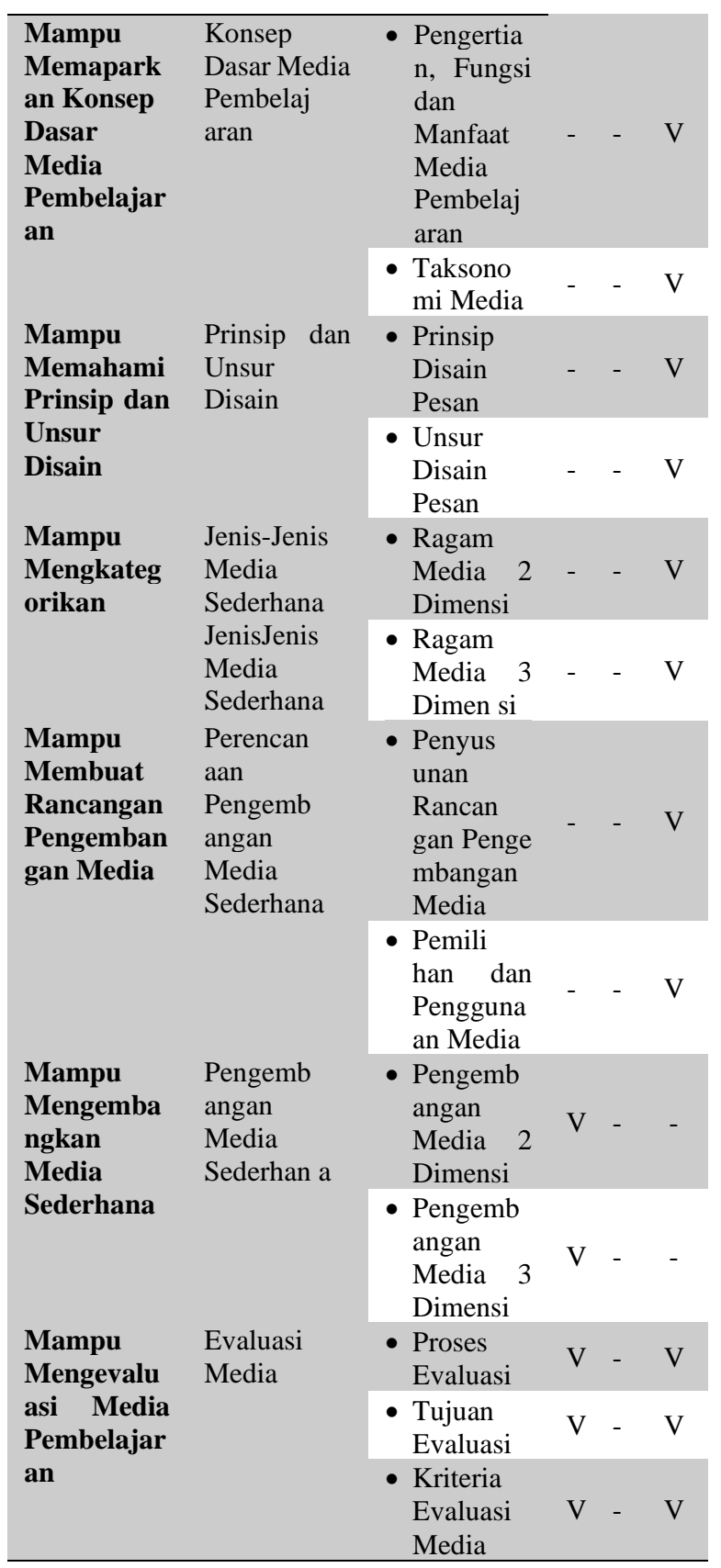


Tabel 6 Contoh Rancangan Aktivitas Pembelajaran Asinkron

Pokok Bahasan 1: Konsep Dasar Media

Subpokok Bahasan 1 : Pengertian, Fungsi dan manfaat media pembelajaran

\begin{tabular}{|c|c|c|c|c|}
\hline \multirow[t]{2}{*}{$\begin{array}{c}\text { Subpokok } \\
\text { Bahasan }\end{array}$} & \multirow[t]{2}{*}{$\begin{array}{l}\text { Pokok } \\
\text { Materi }\end{array}$} & \multicolumn{3}{|c|}{$\begin{array}{c}\text { Strategi Pembelajaran } \\
\text { Asinkron (daring) }\end{array}$} \\
\hline & & $\begin{array}{c}\text { Medi } \\
\text { a } \\
\text { Digit } \\
\text { al }\end{array}$ & $\begin{array}{l}\text { Kegiatan } \\
\text { Belajar }\end{array}$ & $\begin{array}{l}\text { Asesm } \\
\text { en }\end{array}$ \\
\hline $\begin{array}{l}\text { Pengerti } \\
\text { an, } \\
\text { fungsi } \\
\text { dan } \\
\text { Manfaat } \\
\text { Media }\end{array}$ & $\begin{array}{l}\text { Pengertian } \\
\text { Media } \\
\text { Pembelajar } \\
\text { an } \\
\text { Fungsi } \\
\text { Media } \\
\text { Pembelajar } \\
\text { an } \\
\text { Manfaat } \\
\text { Media } \\
\text { Pembelajar } \\
\text { an }\end{array}$ & $\begin{array}{l}\text { Slid } \\
\text { e } \\
\text { dan } \\
\text { Vide } \\
\text { o }\end{array}$ & $\begin{array}{c}\text { Mempelaj } \\
\text { ari Materi } \\
\text { Online } \\
\text { secara } \\
\text { mandiri di } \\
\text { LMS }\end{array}$ & $\begin{array}{c}\text { Kuis } \\
\text { Onlin } \\
\mathrm{e}\end{array}$ \\
\hline
\end{tabular}

Tabel 7 Contoh Rancangan Aktivitas Pembelajaran Sikron

Pokok bahasan 5: Pengembangan Media sederhana

Sub-pokok bahasan 1: Media 2 dimensi (chart)

\begin{tabular}{|l|l|l|}
\hline Jenis & $\begin{array}{l}\text { Kegiatan } \\
\text { Kegiatan }\end{array}$ & Waktu \\
\hline Pembukajaran & $\begin{array}{l}\text { - Dosen } \\
\text { membuka } \\
\text { perkuliahan } \\
\text { dengan }\end{array}$ & \\
menyampaikan & \\
& subpokok & \\
bahasan & \\
& Dosen & \\
& menyampaikan & \\
& capaian & \\
& pembelajaran & \\
& subpokok & \\
& bahasan media & \\
& 2 dimensi chart & \\
& Dosen \\
& menanyakan & \\
& bagaimana & \\
& pengalaman & \\
& belajar \\
& mahasiswa & \\
& serta & \\
&
\end{tabular}

\begin{tabular}{|c|c|c|}
\hline & $\begin{array}{l}\text { menanyakan } \\
\text { kesulitan yang } \\
\text { mungkin ada } \\
\text { dalam } \\
\text { pembelajaran } \\
\text { daring }\end{array}$ & \\
\hline Inti & $\begin{array}{l}\text { - Dosen } \\
\text { melakukan } \\
\text { review materi } \\
\text { yang } \\
\text { sebelumnya } \\
\text { telah diakses } \\
\text { mahasiswa } \\
\text { dalam mode } \\
\text { daring } \\
\text { - Dosen } \\
\text { memberi } \\
\text { arahan } \\
\text { mengenai } \\
\text { praktek } \\
\text { pembuatan } \\
\text { media chart } \\
\text { - Mahasiswa } \\
\text { membuka sesi } \\
\text { tanya jawab } \\
\text { Dosen } \\
\text { menanggapi } \\
\text { dan memberi } \\
\text { penguatan } \\
\text { mengenai } \\
\text { tanya-jawab } \\
\text { mahasiswa } \\
\text { - Mahasiswa } \\
\text { praktek } \\
\text { membuat } \\
\text { media chart }\end{array}$ & 120 menit \\
\hline Penutup & $\begin{array}{l}\text { - Dosen } \\
\text { memberikan } \\
\text { waktu } \\
\text { penugasan } \\
\text { selama 1 } \\
\text { minggu untuk } \\
\text { praktek } \\
\text { pembuatan } \\
\text { media chart } \\
\text { Dosen } \\
\text { memberi } \\
\text { masukan dan } \\
\text { ulasan akhir } \\
\text { serta menutup } \\
\text { perkuliahan }\end{array}$ & 15 menit \\
\hline
\end{tabular}




\section{b. Pengembangan Prototype Produk}

Setelah rancangan desain pembelajaran disusun, maka langkah selanjutnya adalah mengembangkan prototype produk. Pengembangan prototype produk ini menekankan pada produk pembelajaran blended dalam bentuk online course yang diakses pada fip.unj.ac.id/hylearn. Prototype produk dikembangkan dalam bentuk rancangan course yang dilengkapi dengan konten-konten belajar (learning object) pada fip-hylearn.

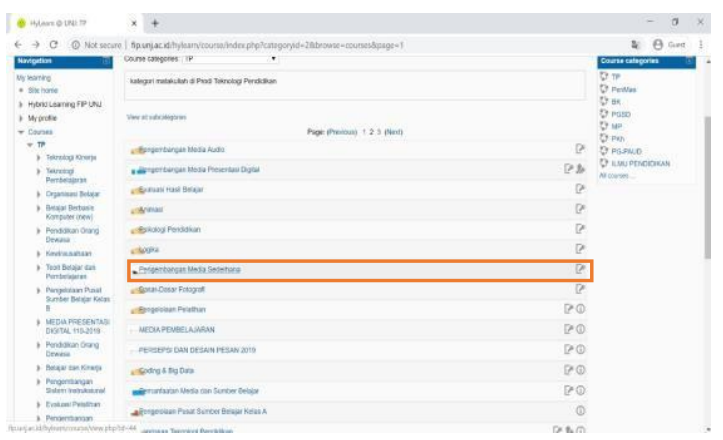

Gambar 2 Penambahan mata kuliah dalam online

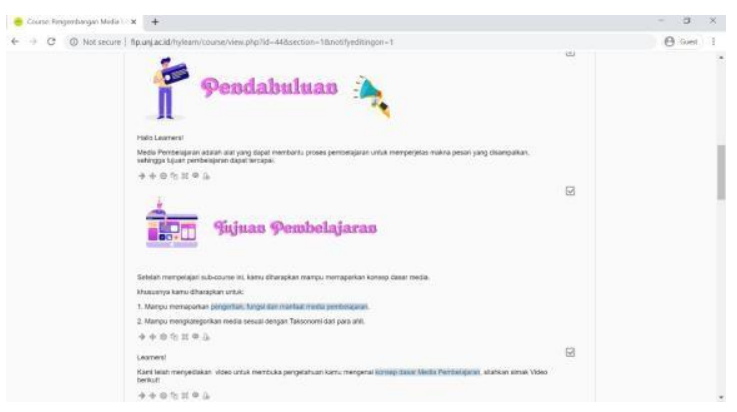

Gambar 3 Pembuatan alur pembelajaran online course.

\section{c. Pengembangan Desain Produk Secara Detail}

Hasil yang diperoleh dari langkah ini adalah produk yang siap untuk di uji coba. Dalam langkah ini, pengembangan mulai melakukan penyusunan penyajian materi (LO), urutan atau langkah pembelajaran dalam online learning, melakukan ujicoba sendiri (Selftesting) terhadap produk yang telah dikembangkan. Self-testing oleh pengembang menjadi rujukan untuk melakukan penyempurnaan detail produk sehingga siap untuk uji coba kepada ahli dan uji coba kepada responden.

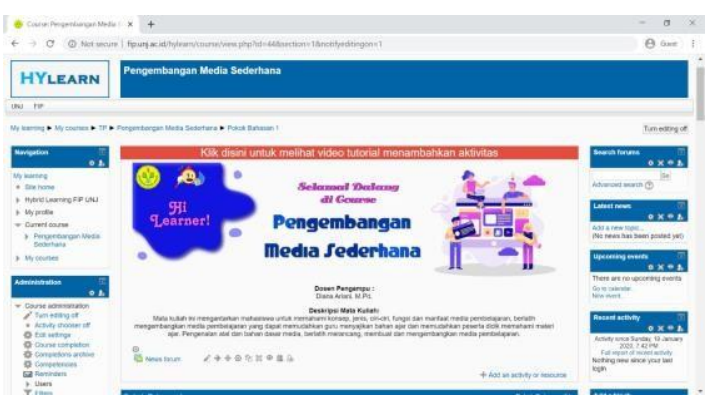

Gambar 4 Contoh tampilan depan produk online course

\section{Tahap Evaluasi}

Hasil ujicoba produk pengembangan expert review ahli materi menunjukkan hasil yang baik dengan presentasi $80,00 \%$, hasil dari expert review media menunjukkan hasil sangat baik dengan presentase $81,5 \%$ dan hasil ujicoba one to one menunjukkan hasil baik dengan presentase $72,25 \%$.

\section{SIMPULAN}

Penelitian pengembangan blended learning untuk mata kuliah Pengembangan Media Sederhana di Program Studi Teknologi Pendidikan, Universitas Negeri Jakarta ini menghasilkan sebuah prototype pembelajaran online di portal web pembelajaran fip.unj.ac.id/hylearn dan disain pembelajaran blended secara keseluruhan untuk mata kuliah Pengembangan Media Sederhana. Penelitian ini dilakukan dengan menggunakan metode ILDF (Integrative Learning Design Framework). Secara umum hasil penelitan ini ditunjukkan dengan hasil ujicoba formatif produk yang dikategorikan baik melalui expert review dan ujicoba one to one.

\section{UCAPAN TERIMA KASIH}

Segala puji dan syukur penulis panjatkan kepada Allah SWT atas kasih dan rahmat-Nya penulis dapat menyelesaikan jurnal ini. Penulis mengucapkan terima kasih kepada semua staff 
dan dosen Program Studi Teknologi Pendidikan yang telah banyak berjasa kepada penulis selama berkuliah di UNJ, terima kasih atas ilmunya. Penulis ingin berterima kasih khususnya kepada dosen pembimbing I yaitu Bapak Cecep Kustandi dan dosen pembimbing II Ibu Retno Widyaningrum yaitu yang telah meluangkan waktu, pikiran dan tenaga serta dengan sabar membimbing dan mengarahkan penulis dalam menyelesaikan skripsi ini. Penulis ingin berterima kasih kepada Ibu Diana Ariani, dan Bapak Kunto Imbar yang telah meluangkan waktunya untuk melakukan expert review.

\section{DAFTAR PUSTAKA}

Clark, Ruth Colvin dan Richard E. Mayer. 2008. ELearning and the Science of Instruction 3rd Edition. San Francisco: Pfeiffer.

Dabbagh, Nada. Brenda Bannan. 2005. Online Learning: Concepts, Strategies, and Application. New Jersey: Pearson Education. Littlejohn, Allison dan Chris Pegler. 2007. Preparing for Blended E-Learning. Oxon: Routledge.

Prawiradilaga, Dewi Salma. dkk. 2013. Mozaik Teknologi Pendidikan: E-Learning. Jakarta: Kencana.Erawati, D. (2014, 1 April) Menengok Intelektualitas di Kota Malang. Diunduh 13 April 2015 dari Kompas.com.: http://bisniskeu angan.kompas.com/read/2015/04/01/2 246008

26/Menengok.Intelektualitas.di.Kota. Malang

Tegeh, I Made.dkk. 2014. Metode Penelitian Pengembangan. Yogyakarta: Graha Ilmu. 